ISBN 978-93-84468-94-1

International Conference on Education, Business and Management (ICEBM-2017)

Bali (Indonesia) Jan. 8-9, 2017

\title{
Decision-Making on Wedding Consumption of GU-PHOTO Company in Kunming
}

\author{
Dr. Chinnaso Visitnitikija, and Yanlin Yang \\ Post graduate school of business administration, Kasem Bundit University, Bangkok
}

\begin{abstract}
The objective was to examine marketing mixes factors affecting decision-making and decision -making process on wedding service purchase of consumers in kunming GU-PHOTO company. It was a quantitative research studying on 385 wedding service purchase consumers.the study tool was questionnaires, and the statistics were percentage, average,one-way ANOVA and regression.

From the result,through 385 questionnaire respondents, most were females, aged between 22-30 years old,monthly income of 1001-5000yuan,complete bachelor degree level and the occupation is businessmen.Overall,opinions on marketing mix factors affecting decision-making to purchase wedding service showed "strongly agree" in product and price aspect, the agreement level were at the high level. In place and promotion aspect, the agreement levels were at highest levels, respectively, from the hypothesis testing, personal factors in gender and education level were not different. in term of age, it showed different at the significance level of .002 in term of occupation, it showed difference at the significance level of .038 .in term of monthly income, it showed difference at the significance level of .028.marketing mixes had relationships on wedding service purchase decision making at the significance level of 0.01 .

For suggestions, wedding service distributors should pay more attention on products and reasonable and negotiable price, company should be available, staffs should have professional knowledge and ability to introduce products with good service to serve customer's demands
\end{abstract}

\section{Keywords: Wedding Consumption}

\section{Introduction}

With the development of China's national economy and the improvement of people's living standards, more than 10 years of China's wedding industry development from the beginning of messy early-stage growing into large-scale progress gradually. Wedding has become a display platform about people's consumption taste from the wedding dresses, wedding photography, wedding services, wedding banquet, jewelry and so on ,each choice makes everyone wants to have a unique wedding. On the other hand the wedding group in $80 \mathrm{~s}$ and $90 \mathrm{~s}$ as the main force, has their own unique understanding and ideas for the wedding, they pay more attention to the wedding spiritual expression of content elements.To satisfy the diversified modern youth, vogue, individuation, the pursuit of romantic ."one-stop wedding service" which provide all the wedding process services you need by a team, now has become an important link of the wedding ceremony. 
The GU-PHOTO wedding company was founded in 2006.After two years of development they officially registered for the wedding service co., LTD., in 2008. GU-PHOTO company is located at center street in Kunming, the company's decoration is very nice with $180 \mathrm{~m}^{2}$.In addition there is a warehouse to hold wedding tools and photographic equipment. They mainly provide wedding planning, wedding photography ,wedding clothes and make-up, wedding Jewry, wedding banquet, and other professional wedding services. The company from the beginning to nowadays, it almost help more than 10,000 couples do wedding planning and execute the wedding activities successfully. But this company exist many problems duo to many factors, so I choose this wedding company as my case study, and put forward the shortage of the wedding service now.

\section{The Purpose of the Study}

(1) this paper will use literature research, questionnaire survey and regular interview aimed at investigating Kunming's wedding service consumption situation.

(2) the purpose is to know about customers' wedding consumption idea, and on the basis of investigation and study, using questionnaire to collect data to analysis, get the influence factors from consumer's decision-making process, and put forward the shortage of the wedding service now.

\section{Hypothesis of the Study}

(1) hypothesize that the personal factors has difference to wedding consumption

(2) hypothesize that the marketing mix related to wedding consumption

\section{Research Methodology}

(1).The theoretical concepts studied by virtue of decision making and marketing mix 4ps consisted of products, prices, distribution channel, and marketing promotion.

(2).Population sample were 385 customers who are retailers at Parg Klong Talad market.

\section{Sample selection}

The samples were 385 consumer who purchased wedding servicein Kunming.

\section{Data collection procedure}

The questionnaires were distributed to sample of 385 consumer who purchased wedding servicein Kunming.A total of 385 usable questionnaires were returned back to the researcher, yielding a 100 percent response rate and no missing data.

\section{Conceptual Frameworks of the Study}

From the study above, the researcher adapted decision-making process and marketing mix theory, as summary and a conceptual framework to study consumption decision-making on wedding service. 


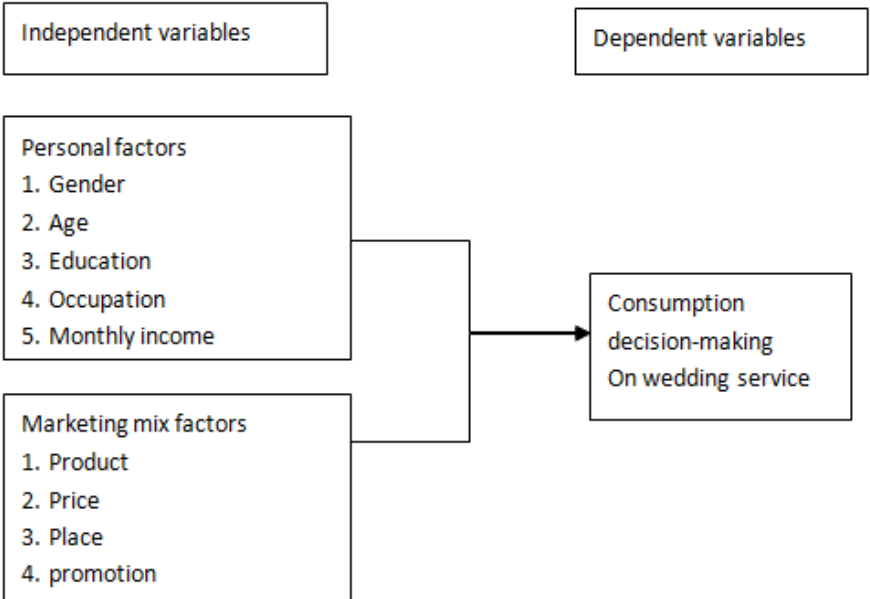

\section{The Test Result of the Data}

Findings indicated that marketing mix factors effecting decision-making on wedding consumption of GU-PHOTO company in Kunming

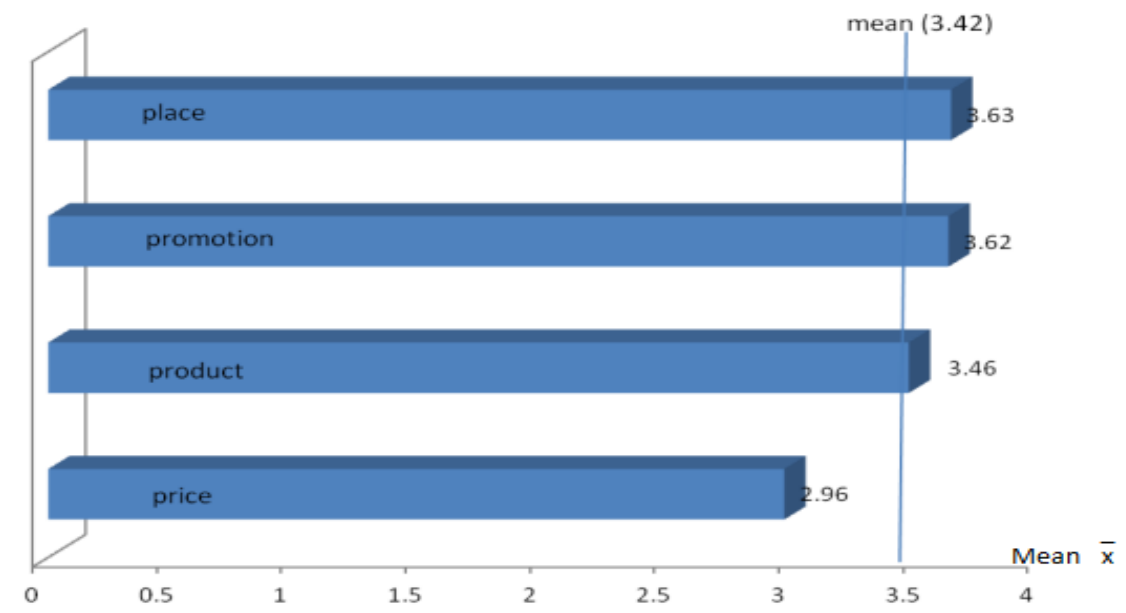

Display the overall picture of marketing mix factors.

From picture we can get information about the Mean of each items of $4 \mathrm{p}$ base on the chart. the mean of place is $(\bar{x}=3.63)$ was in agree level, the mean of promotion is $(\bar{x}=3.62)$ was in agree level. the mean of product is $(\bar{x}=3.46)$ was in agree level, the mean of price is $(\bar{x}=2.96)$ was in medium level.the average mean $(\bar{x}=3.42)$ also in agree level.

TABLE I: hypothesis revealed the regression value, the important of marketing mix factors correlated with decision-making on wedding consumption of GU-PHOTO company in Kunming

\begin{tabular}{|c|c|c|c|c|c|c|}
\hline Factors of Marketing Mix & $\begin{array}{r}\text { Unstandarc } \\
\text { Coefficie }\end{array}$ & & $\begin{array}{l}\text { Standardized } \\
\text { Coefficients }\end{array}$ & 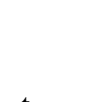 & $\mathrm{S}: \mathrm{O}$ & $T$ T \\
\hline $\begin{array}{l}\text { Constant } \\
\text { product }\end{array}$ & B & $\begin{array}{l}\text { Std. } \\
\text { Error }\end{array}$ & Beta & $l$ & Sig. & Iest resuit \\
\hline wedding clothes and make-up & -.008 & .021 & -.029 & -.377 & .706 & unrelated \\
\hline wedding jewelry & .028 & .020 & .108 & 1.384 & .167 & unrelated \\
\hline wedding site arrangement & .021 & .014 & .084 & 1.539 & .125 & unrelated \\
\hline
\end{tabular}




\begin{tabular}{|c|c|c|c|c|c|c|}
\hline wedding photography & .014 & .020 & .052 & .696 & .487 & unrelated \\
\hline wedding etiquette service & .026 & .012 & .121 & 2.206 & $.028 *$ & related \\
\hline wedding package service & -.041 & .012 & -.183 & -3.368 & $.001 *$ & related \\
\hline \multicolumn{7}{|l|}{ price } \\
\hline package service price & -.015 & .010 & -.077 & -1.451 & .148 & unrelated \\
\hline photography price & -.029 & .012 & -.127 & -2.415 & $.016^{*}$ & related \\
\hline wedding service price & .006 & .012 & .027 & .524 & .601 & unrelated \\
\hline \multicolumn{7}{|l|}{ place } \\
\hline easy to find & -.015 & .014 & -.064 & -1.051 & .294 & unrelated \\
\hline store design nice & .022 & .021 & .077 & 1.045 & .297 & unrelated \\
\hline has many branches & .000 & .019 & .000 & -.005 & .996 & unrelated \\
\hline \multicolumn{7}{|l|}{ promotion } \\
\hline information from newspaper & .000 & .018 & -.001 & -.012 & .991 & unrelated \\
\hline $\begin{array}{l}\text { information from internet or } \\
\text { TV }\end{array}$ & .007 & .017 & .026 & .391 & .696 & unrelated \\
\hline consul from real store & .006 & .018 & .023 & .328 & .743 & unrelated \\
\hline reduce price very often & .008 & .016 & .030 & .475 & .635 & unrelated \\
\hline
\end{tabular}

\section{Discussion}

From table the regression about marketing mix affect wedding consumption decision-making,compared the marketing mix about products,the wedding etiquette service has related to wedding consumption decision-making ( ig.=.028)

The wedding package service has related to wedding consumption decision-making(sig.=.001).compared the marketing mix about price,the wedding photography price has related to wedding consumption decision making (sig.=.016), and these factors affect wedding consumption decision-making the level of statistical significance is .01

From the 4ps marketing mix,the items of place and promotion are unrelated to wedding consumption decision-making.But the items of product,they are wedding etiquette service and wedding package service related to wedding consumption decision-making. the item of price, it's wedding photography price related to wedding consumption decision-making.the sig. is less then .05

\section{Recommendation of the study}

Recommendation from the study of decision making on wedding consumption of GU-PHOTO company in Kunming,wedding service distributors should pay more attention on products and reasonable and negotiable price,company should be available,staffs should have professional knowledge and ability to introduce products with good service to serve customer's demands

\section{Suggestion to Further Study}

This study selected samplings group from consumers at Kunming district only. Therefore, the future study should select samplings group from different demographic area and bring data to compare and get the results to set a new guideline for benefit of all consumers. 


\section{References}

[1] C.Glenn Walters,(1987:69) marketing channel the definition of Decision

[2] LeiXia (2007) An empirical analysis of the consumer purchase decision process

[3] Nicosia,( 1966) consumer purchase decision-making process

[4] RongMei\&ZhouYanli,(2012) The consumer purchase decision and behavior system

[5] Kotler,Philip.(2540).Principles of marketing.9thed., newjersey: prentric-hall

[6] Kotler,Philip.(2546).Principles of marketing. $11^{\text {th }}$ ed., new jersey: prentric-hall

[7] Zhao yixiao(2557), Analysis on the wedding planing service in Yunan's market

[8] Daishuyi (2556), Research on the marketing strategies of XLY wedding company

[9] Zhang peng (2554),Wedding I want my style

[10] Wikipedia.the meaning of wedding consumption 